\title{
The Effect Of Retail Shop Format On Customer Relationship And Customer Loyalty With Customer Trust As Mediation Variables (Case Study : Make Over Retail Stores In Surabaya)
}

\author{
Geodita Woro Bramanti*, Berto Mulia Wibawa, Meuthia Fatah Aulia \\ ${ }^{1}$ Department of Business Management, Institut Teknologi Sepuluh Nopember, Surabaya 60111, Indonesia \\ *Corresponding author.Email: geodita.bramanti@gmail.com
}

\begin{abstract}
To solve these problems, this research aims to analyse the relationship between satisfaction, customer attitude loyalty and customer behaviour loyalty and the influence of different retail formats. The variables used in these research are Satisfaction (S), Trust (T), Attitudinal Loyalty (AL), and Behavioural Loyalty (BL). This research was conducted using a quantitative approach and the data used in this study were obtained from questionnaires to 211 respondents by distributing questionnaires directly (direct survey) to Make Over shops in Surabaya shopping centres. Hypotheses testing in this study use Structural Equation Modelling (SEM). The results of this study indicated that the Satisfaction variable has a positive and significant relationship to the Attitude Loyalty variable and has an influence on Behavioural loyalty through Attitude Loyalty. In addition, the SEM analysis results have a new finding that the Trust variable which is a mediation variable in this study does not have a significant effect on loyalty. From the results of hypothesis testing, this study also formulated managerial implications that can be applied by Make Over as an additional reference to improve service quality in retail stores such as bundling strategies and giving free gifts, implementing referral marketing strategies and focusing on increasing satisfaction
\end{abstract}

Keywords: Cosmetics; Loyalty, Makeup; Satisfaction; Structural Equation Modelling (SEM); Trust

\section{INTRODUCTION}

The development and changes in lifestyle make the growth of cosmetics industry in Indonesia continue to increase from year to year. According to the Ministry of Industry Data in 2018 the number of local cosmetics industries has reached 760 companies where 95 percent of the total companies are the Small and Medium Industry (IKM) sector while 5 percent are large-scale cosmetic industries [1].
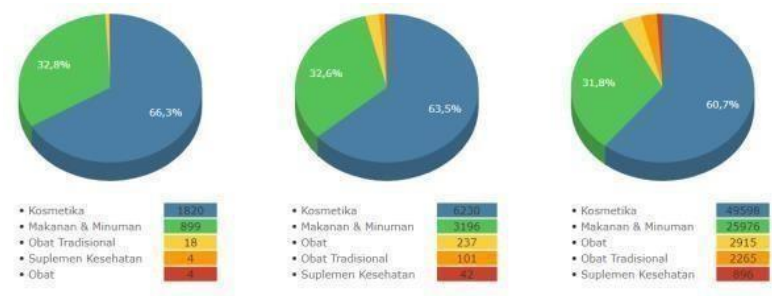

Figure 1. Number of Product that Received Distribution Permit [2] 


\section{Procedia Business and Financial Technology}

Proceedings of the 2nd International Conference on Business and M anagement of T echnology (ICO N BM T 2020) - Part 2

In Indonesian cosmetics market, nearly thousands of cosmetic products already have marketing authorization. Figure 1.1 shows that until the end of September 2019, the circulation of cosmetics in Indonesia reached 49,598 products or around 60.7 percent of the total circulation of Medicinal and Food products [3]. The emergence of many alternative cosmetic products on the market makes it increasingly difficult for producers to satisfy consumer desires. In addition, the ease of access to information results in higher levels of intelligence and knowledge of customers about a product so that their level of awareness of the price and quality of the products offered will increase. This condition can indirectly make it difficult for consumers to be loyal to only one cosmetic brand. The level of difficulty in satisfying customers is also increasing due to the emergence of various kinds of channels (channels) for companies to market their products both online and offline sales or commonly referred to as retail sales. In 2019, the retail business in health and beauty segment is expected to increase by 30 percent, even in the first half of 2019 the growth of the health and beauty retail business has reached 20 percent (yoy) [4]. Retail business growth in cosmetics, skin care and personal care products showed the highest growth value among other health and beauty products, which was 6.2 percent in 2016, 6.4 percent in 2017 , and 6.5 percent in 2018 (Figure 2). The higher level of cosmetics retail sales indicates the increasing competition in cosmetics retailing so this makes cosmetic product marketers to prioritize marketing strategies for each retail store.

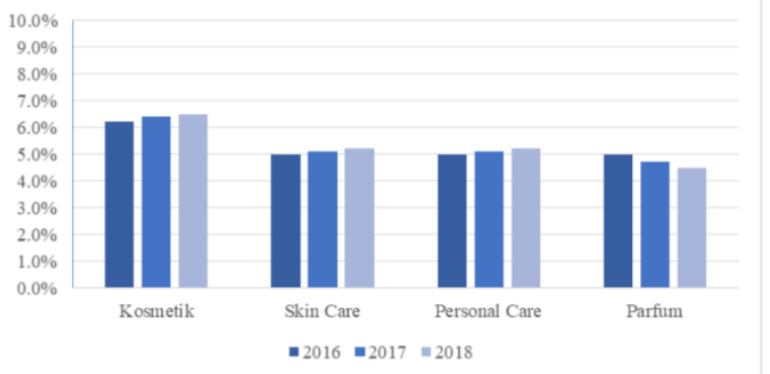

Figure 2. Data on Health and Beauty Retail Growth in Indonesia in 2016-2018[4]

Make Over is one of the leading brands owned by PT Paragon Technology and Innovation and a top of mind brand among make-up lovers, Make Up Artist (MUA), and even the general public. MAKE OVER faced the same problem. Currently, Make Over has several sales channels starting from online, through e-commerce platforms such as Shopee, Tokopedia, Lazada, Sociolla and so on. The offline sales channel form is a singlebrand store which is a retail store that operates only one brand where MAKE OVER also has a retail store of this type which is commonly called the Independent Retail Store. In addition, MAKE OVER also has a type of retail store that another is multi-brand stores where this type of retail store operates several brands in one retail store, the form of this type of store is the Department Store (for example; Matahari Departement Store) and Health and Beauty Store (Guardian, Watson, etc.). In Surabaya, MAKE OVER has 2 (two) Independent Retail Stores located at Tunjungan Plaza 6 and Pakuwon Mall Trade Center and 1 (one) outlet at Matahari Departement Store (Make Over, 2019b). MAKE OVER is also found in every Health and Beauty Store, especially Guardian and Watson in Surabaya shopping centers. MAKE OVER is one of the most popular local cosmetic brands by Indonesian women [5]. Therefore, owning a retail store is very important to increase customer trust and loyalty because the usage of retail stores as an offline sales channel can support the image of a brand and will have a positive influence on the brand [6].

Binninger's research [7] mention that customer satisfaction with a retail brand that has been known will affect customer loyalty at their retail store and satisfaction and loyalty to the retail will indirectly affect customer loyalty to the brand. However, based on the interviews with PT Paragon Technological and Innovation (PT PTI), there was a difference in sales growth in owned retail stores while sales trends in the Department Store MAKE OVER decreased and Independent Retail Stores and Health and Beauty Stores increased. This difference in growth rate is a challenge that must be faced by MAKE OVER.

This research is important considering that there are different levels of growth in the offline sales channel MAKE OVER. That way, this research is directed to discuss the relationship between customer satisfaction and loyalty in the different MAKE OVER retail store formats, that is Single-Brand Store and Multi-Brand Store MAKE OVER in Surabaya. Managerial implications generated based on survey results and some statistical analysis in this study will be in the form of recommendations for specific marketing strategies for each of the Make Over retail store formats studied in order to increase sales of Make Over products through retail stores (offline).

\section{BACKGROUND}

\subsection{Customer Satisfaction}

Customer satisfaction is fundamental for a business. Satisfaction is one of the main measurements in determining a company's success as indicated by attitude, repurchase, and word-of-mouth [8]. In the retail context, customer satisfaction is the result of subjective evaluations where alternative retail stores are chosen according to or exceeding customer expectations [9]. Satisfied customers usually get a positive impression of a product and service offering.

\subsection{Customer Trust}




\section{Procedia Business and Financial Technology}

Proceedings of the 2nd International Conference on Business and M anagement of T echnology (ICO N BM T 2020) - Part 2

Trust is important in business decisions related to uncertainty and dependence where information about products must be disclosed to build customer trust [10]. In the retail context, trust can be interpreted as the expectation of customers that a store and the people and products in it are reliable and can fulfill the promises given to customers [11]. Trust can affect the willingness to buy back aproduct.

\subsection{Attitudional Loyalty}

According to Park [12], attitude loyalty or attitudinal loyalty is loyalty which refers to conditions where customers show their psychological attachment. The research of Dick \& Basu, [9] states that in the context of retailing, attitude loyalty leads to positive attitudes that customers make about a retail store.

\subsection{Behavioural Loyalty}

For a company, customer loyalty becomes more meaningful when they interpret it as buying behavior that makes companies have to build customer loyalty [13]. Some researchers believe that repeated purchases can illustrate customer loyalty to their brands interest [14]. In the retail context, behavioural loyalty leads to repeated buying behaviour by customers in a retail store [9].,

\subsection{Cosmetic Industry}

Cosmetics are materials or preparations intended for use on the outside of the human body (epidermis, hair, nails, lips and external genital organs) or teeth and oral mucous membranes primarily to cleanse, fragrance, change appearance and / or improve body odor or protect or maintain the body in good condition [2].

According to Tranggono \& Latifah, there are 2 (two) classifications of cosmetics based on their usage, namely skin care cosmetics and makeup cosmetics. Skin care cosmetics consist of: (1) Cosmetics for cleaning the skin (cleanser), such as soap, cleansing cream, cleansing milk, and freshener; (2) Cosmetics to moisturize the skin (moisturizer), such as moisturizing creams, night creams, and anti-wrinkle rim; (3) skin protective cosmetics, such as sunscreen cream, sunscreen foundation, and sunblock cream / lotion; and (4) cosmetics for thinning or sanding the skin (peels), such as scrub cream. As for makeup cosmetics, they consist of: (1) Decorative cosmetics to cause effects on the surface and brief use, such as lipstick, powder, blush, eye-shadow, and others; (2) Decorative cosmetics for deep effects and will wear off for a long time, such as skin whitening, hair dye, hair curlers, and others.

\subsection{Retail Store Format}

Basu et al. stated that in developing countries (such as Indonesia) ordinary retail stores are managed in the form of single-brand stores and multi-brand stores. Singlebrand specialty stores are retail stores that only sell and operate one brand, while multi-brand stores are retail stores that offer several brands in a high level store environment and display the position, image and value of a brand.

Single-brand stores represent the uniqueness and characteristics of the brand through the store environment which is commonly referred to as the "store as a brand" strategy where, with this strategy, retail stores can enhance brand identity, differentiate it from competitors and create customer loyalty to the store [15]. In singlebrand stores, customers can feel the identity of the brand which will create loyalty because of strong emotional ties and loyalty [15]. As for multi-brand stores, retail stores must build brand identity by linking their brand names with unique services, diversity of products, store atmosphere, and so on in order to compete with other brands that are competitive in the store area [15].

\subsection{Conceptual Development}

The present research contributes to the case study point of view. The model research adopts the Kamran-Disfani et al. [9]. In more detail, four variables are explored. The four variables consist of Customer Satisfaction (S), Customer Trust (T), Attitudional Loyalty (AL), and Behavioural Loyalty (BL). The model is depicted as ten hypotheses. The entire hypotheses are projected as follow:

H1 : $\mathrm{S}$ has a positive influence and significant on AL

$\mathbf{H 2}$ : $\mathrm{S}$ has a positive influence and significant on $\mathrm{BL}$

$\mathbf{H 3}$ : $\mathrm{S}$ has a positive influence and significant on $\mathrm{T}$

H4 : T has a positive influence and significant on AL

H5 : T has a positive influence and significant on BL

H6 : AL has a positive influence and significant on BL

H7a : The store format (in this case the single-brand store and multi-brand store) has a moderating influence on the relationship between $\mathrm{S}$ and AL.

H7b : The store format (in this case the single-brand store and multi-brand store) has a moderating influence on the relationship between $\mathrm{S}$ and BL.

H7c : The store format (in this case the single-brand store and multi-brand store) has a moderating influence on the relationship between $\mathrm{T}$ and AL.

H7d : The store format (in this case the single-brand store and multi-brand store) has a moderating influence on the relationship between $\mathrm{T}$ and $\mathrm{BL}$

\section{METHODOLOGY}

The present research uses the primary data to test the hypotheses. The instrument data collection is performed through direct survey and online questionnaire on November 2019. The questionnaire is containing twosection, which the first section is asking the demographic, 


\section{Procedia Business and Financial Technology}

Proceedings of the 2nd International Conference on Business and M anagement of T echnology (ICO N BM T 2020) - Part 2

profile and usage data of the respondents. The second section measures the latent variables. The questions are instrumented with a 5-type Likert interval scale, ranging from 1 as "I completely disagree" to 5 as "I completely agree."

The sample in this research are the people who passed the screening stage so that the questionnaire is filled in relevant to the condition of the respondents. Respondents in this study are 18 until 59 years old women who have two requirements such as:

1. MAKE OVER customers in Surabaya who visit the MAKE OVER retail stores at least 5 minutes

2. MAKE OVER customers who buy their products directly at retail stores or had bought their product in the last 3 months.

The estimation of 211 respondents is determined. This number is exceeding the minimum number which is 150 samples.

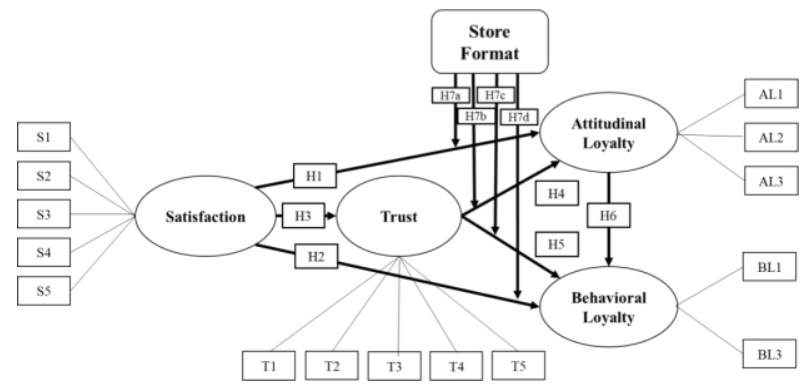

Figure 3. Hypotheses Model

The hypotheses model on this research is analyzed using the Structural Equation Model. The instrument of indicators is projected into Table 1 below:

Table 1. Indicators' Projection

\begin{tabular}{|c|c|}
\hline Variable & Indicators \\
\hline \multirow{5}{*}{$\begin{array}{l}\text { Customer } \\
\text { Satisfaction }(\mathrm{S})\end{array}$} & Satisfaction with purchases(S1) \\
\hline & $\begin{array}{l}\text { Satisfaction with purchases compared to } \\
\text { other stores }(\mathrm{S} 2)\end{array}$ \\
\hline & Satisfaction Level in retail stores (S3) \\
\hline & Service excellence (S4) \\
\hline & Customer expectations (S5) \\
\hline \multirow{5}{*}{$\begin{array}{l}\text { Customer } \\
(\mathrm{T})\end{array}$} & Compliance with the promise given (T1) \\
\hline & Trust in the information provided (T2) \\
\hline & Trust in store credibility (T3) \\
\hline & Trust in store's good intentions (T4) \\
\hline & $\begin{array}{l}\text { Completeness of information provided } \\
\text { (T5) }\end{array}$ \\
\hline \multirow{3}{*}{$\begin{array}{l}\text { Attitudional } \\
\text { Loyalty (AL) }\end{array}$} & Willingness to recommend a shop (AL1) \\
\hline & $\begin{array}{l}\text { Express something positive about the } \\
\text { store (AL2) }\end{array}$ \\
\hline & Store selection (AL3) \\
\hline \multirow{2}{*}{$\begin{array}{l}\text { Behavioural } \\
\text { Loyalty (BL) }\end{array}$} & Majority Purchases (BL1) \\
\hline & Repurchase (BL2) \\
\hline
\end{tabular}

\section{RESULT AND DISCUSSION}

\subsection{Descriptive Analysis}

Descriptive analysis explained the demographic analysis of respondents that were obtained from the respondents data. Descriptive analysis was used to determine the profile of respondents and the behavioural characteristics of respondents towards products and MAKE OVER retail shops in Surabaya. Descriptive analyses were performed using IBM SPSS 23 and Ms Excel 2013 software.

Table 2. Demographic Respondent

\begin{tabular}{|l|l|l|}
\hline Respondent Demographic & Number & $\begin{array}{l}\text { Percentage } \\
(\%)\end{array}$ \\
\hline Age
\end{tabular}




\section{Procedia Business and Financial Technology}

Proceedings of the 2nd International Conference on Business and M anagement of T echnology (ICO N BM T 2020) - Part 2

\begin{tabular}{|c|c|c|}
\hline 18-32 Years Old & 200 & $95 \%$ \\
\hline 33-47 Years Old & 6 & $3 \%$ \\
\hline 48-59 Years Old & 5 & $2 \%$ \\
\hline Total & 211 & $100 \%$ \\
\hline \multicolumn{3}{|l|}{ Education } \\
\hline High School/Equal & 106 & $50 \%$ \\
\hline College / Undergraduate & 101 & $48 \%$ \\
\hline Post Graduate & 4 & $2 \%$ \\
\hline Total & 211 & $100 \%$ \\
\hline \multicolumn{3}{|l|}{ Job } \\
\hline Student & 178 & $84 \%$ \\
\hline Employee & 7 & $3 \%$ \\
\hline BusinessMan/Entrepreneur & 4 & $2 \%$ \\
\hline Civil Servant & 1 & $0 \%$ \\
\hline Private Officer & 12 & $6 \%$ \\
\hline Unemployment & 7 & $3 \%$ \\
\hline Others & 2 & $1 \%$ \\
\hline Total & 211 & $100 \%$ \\
\hline \multicolumn{3}{|l|}{ Salary } \\
\hline <Rp1.000.000 & 58 & $27 \%$ \\
\hline $\mathrm{Rp} 1.000 .000-\mathrm{Rp} 3.000 .000$ & 117 & $55 \%$ \\
\hline $\operatorname{Rp} 3.000 .001-\operatorname{Rp} 6.000 .000$ & 28 & $13 \%$ \\
\hline $\operatorname{Rp} 6.000 .0001-\operatorname{Rp} 9.000 .000$ & 4 & $2 \%$ \\
\hline$>$ Rp9.000.000 & 4 & $2 \%$ \\
\hline Total & 211 & $100 \%$ \\
\hline
\end{tabular}

The respondents are in the age group between 18 to 59 years old. The proportion consists of 95 percent in 18 - 32 years old; 3 percent in $33-47$ years old and 2 percent in 48 - 59 years old.

The education level of the respondent is related to the age of the respondent. The age of most respondents is 18 to 32 years so at that age, most people are sitting in school or university or just graduated from university. The majority of respondent's last education is at the high school / equivalent level which is 50 percent of the total respondents, followed by 48 percent of respondents have completed their education at the Diploma / Bachelor level and the respondents who have the last education at the Postgraduate level are at least as many as 2 percent.

Most Respondents' occupations at the moment are students with 84 percent This is related to the age of respondents who are dominated by respondents 18 to 32 years old. At that age, it is normal that many respondents currently work as students.

Average monthly income of respondents is divided into 5 categories, such as income from parents, husbands, own income, or a mixture of several sources. 28 percent of respondents have income less than Rp1,000,000 and there are 55 percent of respondents who have income between Rp1,000,000 to Rp3,000,000. The average income per month of the respondent is related to the respondent's work. The work is dominated by students or students so that the average monthly income is at most under Rp. $3,000,000$

\subsection{Structural Equational Modelling}

Latent variables that all indicator variables have factor loading are tested for validity and reliability to ensure that the measurement model is accurate and reliable. Validity test is done using Average Variance Extracted (AVE) and factor loading, then there is a reliability test of all latent variables used in which this test aims to determine the extent to which a latent variable produces a response or consistent results when repeated measurements are made. Reliability tests were performed using Cronbach's Alpha (CA) and Composite Reliability (CR) values for each latent variable.

The results of the validity and reliability test show that the loading factor of all indicators has a value above 0.5 which makes the value of AVE, Cronbach's Alpha, and Composite Reliability also meet the cut-off value so that there are no indicator variables that need to be removed. In addition, the measurement model can be declared accurate and reliable and can be used in structural models. The results of the validity and reliability test can be seen in table 3. 


\section{Procedia Business and Financial Technology}

Proceedings of the 2nd International Conference on Business and M anagement of T echnology (ICO N BM T 2020) - Part 2

Table 3. Validity And Reliability TestResult

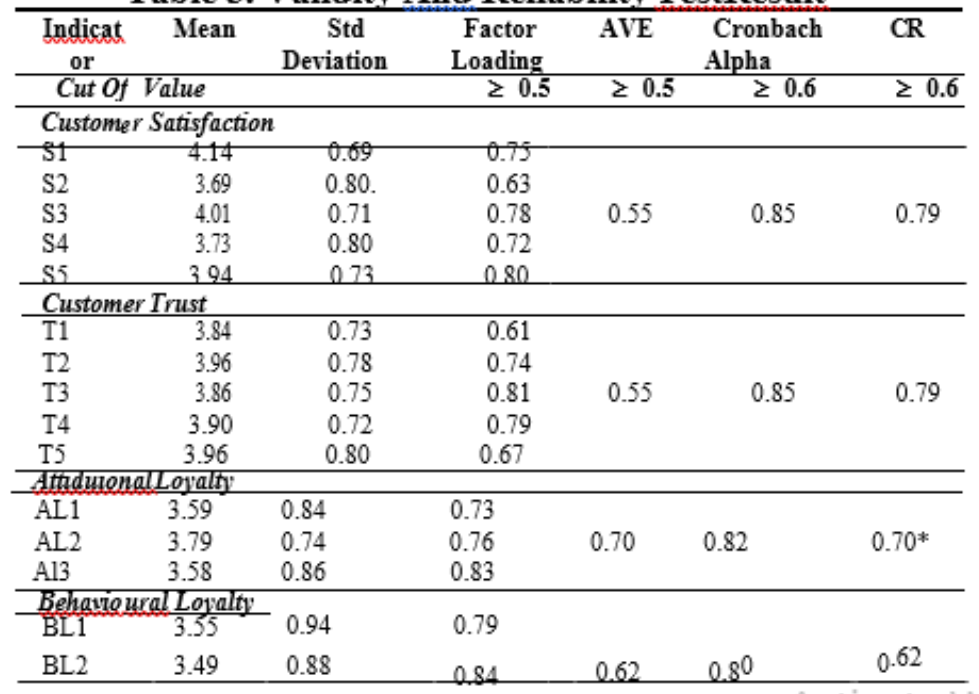

and trust affect behavioural loyalty have no significant direct effect, these conditions are supported by previous research [9] While the negative effect of customer trust on attitude loyalty is contrary to previous research from Kamran-Disfani et al[9]. The results of this study are due to the possibility of customers in Surabaya saying positive things about the Make Over retail store in Surabaya or recommending it to others, not because customers have trust in the store but because of other factors such as recommendations from others, having engagement on social media with the store, etc. coefficient $(\beta)$ of $0,696,0.692$ and 0.818 , respectively. Thus, H2, H4 and H5 are not supported. Both satisfaction

Table 4. Hypotheses Result

\begin{tabular}{|l|l|l|l|l|}
\hline Hypotheses & Beta & p- values & Notes \\
\hline H1 & 0.696 & $* * *$ & Significant & Accepted \\
\hline H2 & -0.036 & 0.797 & $\begin{array}{l}\text { Not } \\
\text { Significant }\end{array}$ & Rejected \\
\hline H3 & 0.692 & $* * *$ & Significant & Accepted \\
\hline H4 & 0.052 & 0.61 & $\begin{array}{l}\text { Not } \\
\text { Significant }\end{array}$ & Rejected \\
\hline H5 & 0.032 & 0.749 & Significant & Accepted \\
\hline H6 & 0.818 & $* * *$ & $\begin{array}{l}\text { Not } \\
\text { Significant }\end{array}$ & Rejected \\
\hline \multicolumn{5}{|c|}{ Note : $* * *=$ less than 0.001} \\
\hline
\end{tabular}

Analysis of the Store Format moderation relationship on the influence of four relationships was carried out using AMOS 20 software. Moderation was done by adding the SF.S variable which is the effect of the merger between SF with S and SF.T variables which is the effect of the merger between $\mathrm{SF}$ with $\mathrm{T}$. The two additional variables are connected to the $\mathrm{AL}$ and $\mathrm{BL}$ variables. The SEM result reveals that all of moderation hypotheses have a smaller standardized coefficient and p-value indicate that the relationship is getting closer to significant. as can be seen in Table 5.

Based on analysis results, several recommendations are proposed from this research;

1. Give special promos for students and students, such as promos with student cards or promos on national education days

2. Maximize in-store customer experience both in terms of service providers (Beauty Assistant) and products 


\section{Procedia Business and Financial Technology}

Proceedings of the 2nd International Conference on Business and M anagement of T echnology (ICO N BM T 2020) - Part 2

quality, display layout, availability of various options, etc.

3. Providing infographic such as brochures in every store that can be used by Beauty Assistant when they give information about Make Over products to customers

4. Providing customer recovery programs such as product warranties, complaint handling forms, and customer service etc.
5. Improved service quality in order to give a positive impression on the store which will lead to repeat purchasing.

6. Implement referral marketing strategies to encourage customers to recommend shops and Make Over products to others.

Table 5. Moderation Effect Result

\begin{tabular}{|l|l|l|l|l|l|l|}
\hline \multirow{2}{*}{$\begin{array}{l}\text { Hypothe } \\
\text { ses }\end{array}$} & \multicolumn{3}{|l|}{ Before } & \multicolumn{2}{l|}{ After } & \multicolumn{2}{l|}{ Moderation SF } \\
\cline { 2 - 7 } & Beta & $\begin{array}{l}\text { p- } \\
\text { values }\end{array}$ & Beta & $\begin{array}{l}\text { p- } \\
\text { values }\end{array}$ & Beta & $\begin{array}{l}\text { p- } \\
\text { values }\end{array}$ \\
\hline $\mathrm{H} 7 \mathrm{a}$ & 0.70 & $* * *$ & 0.23 & 0.38 & 0.50 & 0.20 \\
\hline $\mathrm{H} 7 \mathrm{~b}$ & -0.04 & 0.80 & 0.14 & 0.70 & -0.28 & 0.62 \\
\hline $\mathrm{H} 7 \mathrm{c}$ & 0.05 & 0.61 & 0.34 & 0.19 & -0.39 & 0.29 \\
\hline $\mathrm{H} 7 \mathrm{~d}$ & 0.03 & 0.75 & -0.16 & 0.68 & 0.052 & 0.61 \\
\hline
\end{tabular}

\section{CONCLUSION}

The present research reveals new findings that customer trust, which is a mediation variable, does not have a significant effect on loyalty. This shows that trust in a Make Over retail store is not a matter of making customers loyal to the store and the Make Over brand, both from the intention to recommend the store, saying positive things, and especially to the repurchase behavior. However, with the store format variable as a moderating variable, the relationship between customer satisfaction and attitude loyalty is getting weaker, the relationship between customer satisfaction and attitude loyalty is getting weaker, the relationship between customer trust and loyalty attitude which is initially positive becomes negative and getting closer to significant, and the relationship between customer trust and loyalty attitudes become stronger and closer to significant.

Based on this research, the step that MAKEOVER management must do are giving special promotion, maximize in store customer experiences, providing infographics, recovery programs and also implement referral marketing. This research has several limitations, such time collection, object research scope and no sentence structure changes were made on the questionnaire. Exploring the online and offline sales channel in MAKEOVER is highly suggested

\section{REFERENCES}

[1] Kemenperin, "Industri KosmetikNasional Tumbuh 20\%." 2018. [Online]. Available: https://kemenperin.go.id/artikel/18957/Industri-

Kosmetik-Nasional-Tumbuh-20
[2] B.P.O.M., "Statistik Produk Yang Mendapat Persetujuan Izin Edar.” 2019. [Online]. Available: https://cekbpom.pom.go.id/

[3] B.P.O.M., "Peraturan Kepala Badan Pengawas Obat Dan Makanan Republik Indonesia Nomor 11 Tahun 2017 Tentang Kriteria Dan Tata Cara Penarikan Dan Pemusnahan Kosmetika.” 2017.

[4] Bisniscom, "Bisnis Ritel Kesehatan \& Kecantikan Diproyeksi Tumbuh 30\% Tahun Ini.” p. 30-, 2019. [Online]. Available: https://ekonomi.bisnis.com/read/20190902/12/114 3589/

[5] H. Media, “10 Merek Kosmetik Lokal Indonesia Paling Favorit Untuk Paras Cantikmu.” p. 2, 2018. [Online]. Available: https://highlight.id/daftarbrand-

[6] J. Semeijn, A. C. R. Van Riel, and A. B. Ambrosini, "Consumer evaluations of store brands: effects of store image and product attributes," Journal of Retailing and Consumer Services, vol. 11, no. 4, pp. 247-258, 2004.

[7] A.-S. Binninger, "Exploring the relationships between retail brands and consumer store loyalty," International Journal of Retail \& Distribution Management, vol. 36, no. 2, pp. 94-110, 2008.

[8] P. Huddleston, J. Whipple, R. Nye Mattick, and S. Jung Lee, "Customer satisfaction in food retailing: comparing specialty and conventional grocery stores," International Journal of Retail \& Distribution Management, vol. 37, no. 1, pp. 6380, 2009.

[9] O. Kamran-Disfani, M. K. Mantrala, A. IzquierdoYusta, and M. P. Martínez-Ruiz, "The impact of retail store format on the satisfaction-loyalty link: An empirical investigation," Journal of Business Research, vol. 77, pp. 14-22, 2017.

r




\section{Procedia Business and Financial Technology}

Proceedings of the 2 nd International Conference on Business and M anagement of T echnology (ICO N BM T 2020) - Part 2

[10] R. Chinomona and D. Dubihlela, "Does customer satisfaction lead to customer trust, loyalty and repurchase intention of local store brands? The case of Gauteng Province of South Africa," Mediterranean Journal of Social Sciences, vol. 5, no. 9, p. 23, 2014.

[11] P. Guenzi, M. D. Johnson, and S. Castaldo, "A comprehensive model of customer trust in two retail stores," Journal of Service Management, vol. 20, no. 3, pp. 290-316, 2009.

[12] S.-H. Park, "Relationships between involvement and attitudinal loyalty constructs in adult fitness programs," Journal of Leisure Research, vol. 28, no. 4, pp. 233-250, 1996.
[13] M. S. Pepe, R. Abratt, and P. Dion, "The impact of private label brands oncustomer loyalty and product category profitability," Journal of Product \& Brand Management, vol. 20, no. 1, pp. 27-36, 2011.

[14] S. andyopadhyay and M. Martell, "Does attitudinal loyalty influence behavioral loyalty? A theoretical and empirical study," Journal of Retailing and Consumer Services, vol. 14, no. 1, pp. 35-44, 2007.

[15] W. Koo and Y. Kim, "Impacts of store environmental cues on store love and loyalty: single- brand apparel retailers," Journal of International Consumer Marketing, vol. 25, no. 2, pp. 94-106, 2013. 